\title{
Statyba
}

\section{SOME THOUGHTS ON CIVIL ENGINEERING STUDY PROGRAMMES}

\section{A. Čižas}

To cite this article: A. Čižas (1999) SOME THOUGHTS ON CIVIL ENGINEERING STUDY

PROGRAMMES, Statyba, 5:3, 166-169, DOI: 10.1080/13921525.1999.10531457

To link to this article: https://doi.org/10.1080/13921525.1999.10531457

曲 Published online: 26 Jul 2012.

Submit your article to this journal $₫$

Џ Article views: 73 


\section{MINTYS APIE STATYBOS KRYPTIES STUDIJUQ PROGRAMAS}

\section{A. Čižas}

\section{Studijy programy gausa ir jvairovè}

Lietuvai atkūrus nepriklausomybę ir aukštosioms mokykloms èmus plačiai naudotis autonomija, sparčiai gausejjo studiju programų. $1999 \mathrm{~m}$. Lietuvoje teikiamų ivairių sričių ir krypčių pagrindiniu studiju programų buvo per keturis šimtus, ne mažiau programy buvo skirta magistrantūrai ir specializuotosioms profesinèms studijoms. Kai kurias naujas studiju programas atsirasti skatino darbo rinkos poreikiai, tačiau šie poreikiai anaiptol nepateisina skirtingu studiju programu gausos. Galima spèti, kad programų gausinimą stjmuliavo kai kurios valstybinio universitety reguliavimo bei finansavimo mechanizmo detalès (antai planini primamy studentų skaičių ministerija nustatydavo atskirai kiekvienai studiju programai; dabar šis skaicius nustatomas jau studiju krypčiai, nepaisant tos krypties programų skaičiaus).

Programų gausa „tebeserga“ ir statybos krypties studijos. Valstybiniame programu registre $1999 \mathrm{~m}$. buvo irašyta 12 skirtingai pavadintų statybos krypties pagrindiniu studiju programų, 10 magistrantūros ir 5 specializuotuju profesiniu studiju programos (1 lent.). Ypač didelių abejonių kelia pagrindinių studiju programų sąrašas. Iš pavadinimų neaišku, kuo skiriasi statybos ir statybos inžinerijos studijy programos; juo labiau neaišku, kas tai yra civiline inžinerija (taip pavadinta pagal anglišką terminą civil engineering, kuriuo tradiciškai vadinama statyba arba statybos inžinerija plačiaja prasme, atskiriant ją nuo kitu trijų inžinerijos šaku - mechanikos inžinerijos, elektros inžinerijos ir chemijos inžinerijos). Neatrodo pagrịsta VGTU teikiamo miestụ ir kelių inžinerijos studiju programu komplekso struktūra. Itin specialūs studijų programu pavadinimai perša minti, kad pačios studijos pagal tokias programas nèra universitetinès, kad jomis ketinama teikti labai specializuotą neuniversitetini profesini aukštaji išsilavinima.

Magistrantūros programu ivvairovè galètụ būti didesnè negu pagrindiniu studiju, nes sios studijos turi būti labiau susietos su moksliniais tyrimais ir būtent

su tyrimais, kurie vyksta tame universitete. Mokslinių tyrimu tematika universitetuose labai ivairi, ir skirtingos tematikos moksliniais tyrimais paremtos magistrantūros studijos gali būti labai skirtingos, ju ypatumus turètu rodyti ir programu pavadinimai. Deja, kaip matyti iš programy sąrašo, tokios informacijos stinga.

1 lentelè. Statybos krypties studiju programos

Table 1. Civil engineering study programmes

\begin{tabular}{|ll|}
\hline \multicolumn{1}{|c|}{ Programos } & Universitetai \\
\hline Pagrindiniu studiju programos & \\
Civilinè inžinerija & VGTU \\
Hidrotechnika & LŽUUU \\
Keliu inžinerija & VGTU \\
Miestų inžinerija & VGTU \\
Miestu ir kelių inžinerija & VGTU \\
Statyba & VGTU \\
Statybos inžinerija & KTU, KU, ŠU \\
Statybos medžiagos ir dirbiniai & VGTU \\
Statybos konstrukcijos & \\
ir technologija & VGTU \\
Energetikos ir transporto statyba & VGTU \\
Statybos valdymas & VGTU \\
Pastatu inžinerinès sistemos & VGTU \\
& \\
Magistrantūros programos & \\
Civilinè inžinerija & VGTU \\
Geotechnika & VGTU \\
Hidrotechnika & LŽÜU \\
Statiniu konstrukcijos & VGTU \\
Statyba & VGTU \\
Statybos inžinerija & KTU \\
Uosto statiniai & KU \\
Medžiagotyra & \\
(statybos medžiagos) & VGTU \\
Statybos medžiagos ir dirbiniai & VGTU \\
Statybos valdymas & VGTU \\
Specializuotuju profesiniu studiju & \\
Hidrotechnika & LŽÜU \\
Keliai ir geležinkeliai & VGTU \\
Miestų inžinerija & VGTU \\
Statyba & \\
Statybos medžiagu & \\
ir dirbinių technologija & \\
\hline
\end{tabular}




\section{Studijų pakopos ir pobūdis}

Dabar Lietuvos universitetuose vyksta statybos krypties studijos pagal keturiu skirtingy lygiu programas: pagrindinès ketverių mety studijos, baigiamos akademiniu bakalauro laipsniu, ir trejopos podiplominès studijos - dvimete magistrantūra (baigiama akademiniu magistro laipsniu), vieneriu metu specializuotosios profesinès studijos (po kurių igyjama nevisiškai aiški „diplomuoto inžinieriaus“ kvalifikacija) ir keturmeté doktorantūra (po jos, apgynus disertacija, suteikiamas daktaro mokslo laipsnis).

Trys pakopos sudaro nuosekliu universitetiniu studiju srautą ir atitinka daugelio šalių ir ivairiu krypčiu studiju struktūrą. Tačiau vadinamosios specializuotosios profesinès studijos nesuderintos su šia struktūra, jụ egzistavimo priežastis yra klaidingas pagrindinių studijụ nepilnavertiškumo jvaizdis. Tokio ivvaizdžio pasekmé - siūlymai atsisakyti pagrindinių studiju baigiamojo darbo, taip akademini bakalauro laipsni visiškai nuvertinant (beje, KTU statybos inžinerijos pagrindiniu studiju programoje baigiamojo darbo nebèra numatyta, diplominis projektavimas irašytas tik i specializuotuju profesiniu studiju programa, taip paverčiamą kone būtinu pagrindinių studiju tęsiniu).

Dabar teikiamy specializuotuju profesiniu studiju programose dar dažnokai pakartojami pagrindiniu studiju dalykai - kiek praplesti ir šiek tiek pakeistais pavadinimais. Tai iliustruoja 2 lentelè, kurioje palyginti kelių modulių pavadinimai iš dviejų VGTU programu [1] - pagrindinių studiju (1a - statybos medžiagos ir dirbiniai bei $2 a-$ miestu inžinerija) ir specializuotuju profesiniu ( $1 b$ - statybos medžiagu ir dirbiniu technologija bei $2 b$ - miestu inžinerija).
„Diplomuoto inžinieriaus“ kvalifikacijos (ar laipsnio) prasmingumu jau abejojama ir Vokietijoje, kur rengiamasi persiorientuoti i dvipakope studijy sistema ir pasinaudoti magistrantūros galimybèmis $[2, \mathrm{p}$. 122]. Pagaliau toks „diplomuoto inžinieriaus" „titulas“ aiškesnę prasmę igautu, jeigu ji teiktu ne aukštoji mokykla, bet profesinè organizacija, pavyzdžiui, statybos inžinierių sajunga, atsižvelgdama ne vien i asmens išsimokslinima, bet ir $i$ jo profesinę patirti. O gal pavyktų šiai kvalifikacijai rasti tinkamesni lietuvišką pavadinimą, kuris, pavyzdžiui, atitiktų anglišką chartered engineer.

Sunku parinkti tinkamiausią statybos krypties studiju pobūdi jo diapazonas labai platus - nuo gana akademinių, fundamentaliu studijų, vedančiu i statybos mokslo aukštumas, iki labai praktinio profesinio ir anaiptol ne universitetinio specialistų rengimo konkrečioms darbo vietoms. Tu studiju spektro viduryje galima ¡žvelgti ir universitetines profesines studijas: jos galètu bũti skirtos rengti ne ,generalistus“, bet statybos profesijos strategus, gerai išmanančius apie visas tiek projektavimo, tiek statybos industrijos galimybes ir sugebančius kurti profesinès veiklos strategija. Vargu ar kuri nors iš dabartinių universitetinių statybos studiju programu yra orientuota i toki tiksla.

Jeigu per ketverius metus parengti gero profesijos stratego neimanoma, reikia tai irodyti ir pasiūlyti ketveriu su puse ar net penkerių mety universitetiniu profesinių studiju programas, juoba kad daugumoje Europos šaliu universitetinių statybos studiju programu trukmè yra penkeri metai. Negali būti abejonių - kas yra taupiau: ar rengti žmogų neaiškiam darbui ketverius metus ir po to papildomai dar metus mokyti, ar pagal vientisą nuosekliu ilgesnių studiju programą mo-

2 lentelè. Panašūs dalykai skirtingo lygio programose

Table 2. Similar subjects in programmes of different level

\begin{tabular}{|c|c|}
\hline Pagrindinių studijy programa & Specializuotujy profesinių studiju programa \\
\hline $\begin{array}{l}\text { Ia - Statybiniu dirbiniu gamybos projektavimas (2 kred.) } \\
\text { Statybiniu medžiagu ir gaminių standartai } \\
\text { ir normos }(2,5) \\
\text { Rinkodara ir investicijos (3) } \\
2 a \text { - Miesto gatvè ir keliai (4) } \\
\text { Statinių eksploatavimas (2) }\end{array}$ & $\begin{array}{l}\text { Ib - Statybos dirbinių technologijos projektavimas }(2,5) \\
\text { Standartizacija ir kokybès valdymas }(4) \\
\text { Statybos pramones rinkodara (4) } \\
2 b \text { - Miestụ transportas ir gatvès }(4+3) \\
\text { Statinių priežiüra (2) }\end{array}$ \\
\hline
\end{tabular}


kyti iškart žinomam tikslui. Ir akademini bakalauro laipsni teikti derètų tik parengtiems profesinei veiklai absolventams, o ne ,pusfabrikačiams“"

Specialistus siaurai apibrèžtiems inžinerinio darbo barams rengti reikètu palikti neuniversitetinèms studijoms - trumpesnèms, gal net trejų metų. Joms kelią atvers numatoma binarinė aukštojo mokslo sistema. Laikas jau dabar apgalvoti, kokias statybos krypties studiju programas galima ir reikia atidalyti nuo universitetiniu studiju, t. y. kokias ju gali realizuoti ne tik universitetai, bet ir būsimos naujo tipo aukštosios mokyklos - kolegijos.

Lig šiol Lietuvos aukštojo mokslo sistemoje nèra iki galo aiškus magistrantūros studiju statusas. Savaip šias studijas traktuoja kiekvienos programos tvarkytojai bei vadovai. Stengiamasi vykdyti kvalifikacini reikalavimą sieti šias studijas su moksliniais tyrimais, tačiau tokiu sąsaju mastas labai skirtingas. Nors vienas iš magistrantūros tiksiu yra rengtis doktorantūros studijoms ir mokslinei veiklai, anaiptol ne visi magistrai (ir net ne dauguma ju) stos i doktorantūrą. Magistro lygio išsimokslinimo, sugebejimo naudotis mokslo laimejjimais ir atlikti tyrimus (ne vien mokslinius, bet ir gamybinius) reikia ir profesinès veiklos pozicijoms. Todel leistinos ir net skatintinos profesiniu magistrantūros studiju programos. Dabar teikiamose statybos krypties magistrantūros programose specialiu profesinių dalykų nestinga, bet galima pasigesti nauju fundamentinių (matematikos, mechanikos ir kt.) disciplinı, be kurių sumenkejja ir susipažinimo su moksliniais tyrimais verte.

Atskirai aptartinas prièmimo į magistrantūrą klausimas. Dabar beveik visi magistrantai yra ką tik baige to paties universiteto (ir tos pačios katedros kuruojamas) pagrindines studijas. Tačiau magistro erudicija būtų tikrai daug platesné, jeigu abieju pakopu studijos vyktu skirtinguose universitetuose arba jeigu i magistrantūrą būtu ateinama bent jau po poros ar keleriu profesinès veiklos metú.

Nemaža dalis statybos inžinerijos krypties doktorantūros studiju taip pat yra orientuota i profesiniu problemų sprendimą. Ir daktaro mokslo laipsni igijusieji dirba ne tik mokslo ir studiju institucijose. Ilgainiui, vis tobulejant gamybinèms technologijoms, daktaro lygio kvalifikacija taps net būtina kai kuriems statybos pramonès profesionalams.

\section{Studiju programų sandara, studijų kokybės palaikymas}

Kone visos statybos krypties studiju programos sudarytos iš pernelyg smulkiu moduliu - vyrauja dvieju-triju kreditu kursai. Todèl per semestrą būna studijuojami šeši-septyni, o kartais net ir daugiau dalyku. Tiek ir egzaminu tenka išlaikyti per vieną sesiją. Studento démesys išskaidomas, ryšiai tarp studijuojamy modulių lieka reikiamai neapibréžti, studiju visuma studento sunkiau suvokiama. Programose turèty vyrauti keturių-penkiu kreditu moduliai, o per vieną semestrą studijuotini ne daugiau kaip penki dalykai.

Daugeliui programų trūksta laisvumo, jose pernelyg didelis privalomuju dalyku skaičius, per maža studento pasirinkimo laisvè - dažniausiai jis gali rinktis tik vieną ar kitą studiju pakraipa, neskatinamas studiju programu komponavimas pagal individualius studento poreikius ar norus. Net ir kai kuriu programy „laisvu pasirinkimu“ pavadinta studiju dalis apribota tik vienu dalyku, kuris pasirenkamas iš dvieju-triju siūlomų. Reikètų kiekvienam studentui leisti pasirinkti bent apie penkis procentus studiju - iš visų universitete ir gal net kituose universitetuose teikiamy kursu. Tokiai laisvei, be abejo, kliudo sena studiju organizavimo tvarka, pernelyg stipriai susieta su neskaidomomis studentu grupèmis.

Nepakankamos universitety pastangos unifikuoti studiju modulius ir tuo mažinti destytoju krüvi, mažinti studijų kainą. Yra panašių moduliụ, rengiamų net skirtingose katedrose (plg. VGTU Keliu katedros transporto statiniai $I$ ir Gelžbetoniniu konstrukciju katedros keliu statiniai arba Miestu statybos katedros statybos procesai ir Statybos technologijos ir vadybos katedros statybos technologija). Vargu ar naudinga studijoms tokia katedru ir fakultety konkurencija - ar nebūtu geriau sutelkti bet kurio dalyko kvalifikuotas mokslines ir metodines pajègas i vieną universiteto branduoli ir sustiprinti fakultetu bendradarbiavimą. Universitetai neturètų virsti fakultetu asociacijomis, jų stiprybè glūdi būtent kryptingoje, gerai valdomoje labai kvalifikuotu fakultetu sąveikoje.

Sudarant studiju programas būtina atsižvelgti $\mathfrak{i}$ tris studiju poreikio komponentus: 1) ar darbo rinkai reikia tokių studiju absolventu, 2) ar bus norinčiu tai studijuoti ir 3) ar yra metodinè, materialioji tokiu studiju baze ir kvalifikuotas personalas. Kadangi programas sudaro katedros, neretai remiamasi daugiausia trečiuoju poreikio komponentu: studiju programos visu pirma reikia ne darbo rinkai, ne studentams, bet katedros dèstytojams, kad jiems užtektı darbo, kad katedros metodinis idirbis neprarastu vartojamosios vertès. Ir programu sandara neretai būna orientuota visu pirma i esama katedros pajègumą. 
Galbūt tokiu katedrụ poreikiu galima paaiškinti ir gelžbetonio studiju dominavimą statybos krypties studiju programose, nors šios konstrukcijos statybos industrijoje prarado pirmykštes pozicijas. Be jokios abejonès, katedrų ir universitetu biblioteku per ilga laika sukaupta ir jau pasenusi literatūra taip pat yra atsilikimo priežastis. Turimi literatūros fondai tampa beverčiais studijuojantiems net ir mažai tekintančius teorinius dalykus, nes didžioji dalis sukauptų knygu yra rusų kalba, kurios dabartiniai studentai jau nebemoka. Literatūros fondams atnaujinti universitetai stokoja leš̌uc.

Pagrindiniams statybos krypties studiju orientyrams nustatyti reiketu sutelkti kvalifikuotas akademines pajègas iš visu tokias studijas teikianciu universitetu. Galima tikètis, kad 1999 m. atliekama visu šios krypties studiju programu savianalizè ir ekspertizè padès tai padaryti. Nepaneigiant universitetų autonomijos (ypač akademinių sprendimų srityje), būtina susitarti dèl bendru statybos studiju dalykų. To reikia studentų mobilumui, kad jie galètų studijuoti kai kuriuos kursus skirtinguose universitetuose, net skirtingose šalyse, pereiti iš vieno universiteto i kita.

Tiek Sorbonos [3], tiek Bolonijos [4] deklaracijose Europos šaliu ministrai pagristai skelbia bendros Europos aukštojo mokslo erdvès kürimo bütinybę. Tarsi atsiliepdamas i tai, "Socrates“ programos projektas „Europos Sajungos statybos inžinierių studijos ir mokymas" (EUCEET) siekia sukurti prielaidas bendroms statybos studiju programu gairems. Atsiveriant Europos šaliu sienoms, išsiplečia statybos inžinieriu darbo rinka, bet kartu atsiranda nauju bendru kvalifikaciniu reikalavimu, prie kuriu tenka derinti ir studiju programas. Tik pagal tokias programas igyta kvalifikacija bus pripažistama visose šalyse ir tik tokios programos galès būti akredituotos.

\section{Literatura}

1. Vilniaus Gedimino technikos universitetas. Studiju programos 1998-2000. Vilnius: Technika, 1998. 244 p.

2. Zukunft der Ingenieurausbildung an Fachhochschulen. Beitrage zur Hochschulpolitik, 2/1999. Bonn: Hochschul Rektoren Konferenz, 1999. 146 S.

3. Joint Declaration on Harmonisation of the Architecture of the European Higher Education System by the four Ministers in charge for France, Germany, Italy and the United Kingdom. Paris, the Sorbonne, May 25, 1998.

4. The European Higher Education Area. Joint Declaration of the European Ministers of Education. Convened in Bologna on the 19th of June 1999.

Iteikta $199907 \quad 12$

\section{SOME THOUGHTS ON CIVIL ENGINEERING STUDY PROGRAMMES}

\section{A. Čižas}

$\mathrm{S} \mathrm{u} \mathrm{m} \mathrm{m}$ ar $\mathrm{y}$

More than four hundred study programmes are registered in Lithuanian higher education institutions for undergraduate level, and the same number for postgraduate studies. Any demand of a labour market cannot substantiate such an abundance of programmes. Some details of the previous mechanism of financing universities had stipulated the increase of the number. Sickness of the abundance is characteristic of the civil engineering subject area as well. In Table 1 there are listed all the programmes in this subject area: 12 different programmes for undergraduate, 10 for Master, and 5 for specialised professional studies. Some very specialised names of programmes make us suppose the programmes are for non-university studies.

Basic (undergraduate), Master and Doctoral studies make a consistent system of Lithuanian civil engineering higher education. Specialised one-year professional postgraduate study programmes do not fit to the system, they have been provoked by a wrong image of inferiority of undergraduate programmes. Similar subjects are included into both undergraduate and "professional" study programmes (examples are presented in Table 2). The title of Dipl Eng could be justified if it would be awarded by any professional body, not by universities. If it is necessary to lengthen duration of civil engineering education, it is better to substitute the four-year undergraduate programmes for five-year ones.

Binary higher education system is coming to Lithuania, non-university study programmes and higher education institutions (colleges) will be introduced. Civil engineering study programmes fitting for this new higher education sector should be selected.

Almost all the civil engineering programmes consist of very small courses (mostly of two-three credits), and six-seven subjects are studied every term. It is reasonable to shorten the term list up to five subjects, not more.

Some efforts of civil engineers are directed to creating a common European higher education area according to the Sorbonne and Bologna declarations [3, 4]. The European Union Civil Engineering Education and Training Thematic Network Project (EUCEET) has a task to elaborate common requirements of curriculum, quality assessment and mutual recognition of the higher education.

Algirdas Eduardas Čižas. Doctor Habil, Professor. Dept of Strength of Materials. Vilnius Gediminas Technical University, Sauletekio al. 11, 2040 Vilnius, Lithuania.

Both Doctoral theses $(1967,1974)$ were devoted to the problems of structural optimisation. 1976-94 Head of the Dept of Strength of Materials, 1980-87 Dean of Civil Engineering Faculty. Author of textbooks. Research interests: structural optimisation, analysis of elastic-plastic strain-hardening structures, quality assessment in higher education. 